\title{
THE NEW URBANISM OF FISHERMEN'S VILLAGE IN BULAK SETTLEMENT SURABAYA
}

\author{
Ratna Darmiwati \\ Departement of Architecture \\ Institut Teknologi Sepuluh Nopember, Surabaya \\ Darma Cendika Catholic University, Surabaya \\ Indonesia \\ e-mail: ratnadarmiwati@gmail.com
}

\begin{abstract}
Based on the existing potential characteristics, Surabaya is developed to function as the nation's center of main area $C$, that covering areas in the east and north of Indonesia. The nation's target in city development are field of industry, trading, maritime, garrison and tourism. Land condition in Surabaya is not fully urban, because there are areas with rural use such as paddy field, moor, ponds and coastal forest. The rural use of land are found in west, south-west and eastern part of Surabaya. The condition shows that the activity is dual, which are urban and rural. It is related with the environment which is hilly topography at the western part of Surabaya and shore at the eastern part of Surabaya. The scope of study research is identification that is conducted in a fishermen's settlement of Bulak, Surabaya. The identification covered physical and non-physical aspects of the area. The environment and buildings' condition and land use are covering demography, social economic and culture condition. The research method is conducted by inventory of data, using the observation technique, interview, and documentation, moreover visual observation. The use of theory is related to the fishermen's settlement, sense of place and new urbanism. Result of the research is a strategy concept in efforts to renewal the fisherman's area based on physical and non-physical characteristics. Consist of "Government and community participation are needed for renewal settlement in fishing village. The guidance of local government was needed on various small business opportunities, where process is quite simple and profitable for low income people. They have to demonstrate the balance between 'man-housesenvironment', so that the relation between them can be dynamic and sustainable. The existence of houses in fishing area need a private bathroom with good sanitation and septic tanks, for environment preservation. They need to obtain good economic opportunities are promising for low income level. The some environments in coastal area need electricity services especially in study area.
\end{abstract}

Keywords : Fishermen village, Physical characteristics, Non physical characteristics. 


\section{INTRODUCTION}

The Surabaya city development showed the dualism in land use, where most of its use in urban and rural character. That looks use for upland, wetland, ponds, coastal forest, and fishing occupancy. The fishermen are still often found in east coast along, that opposite with the western part of Surabaya there are hilly land. While the central part of the city is flat land where the Kali Mas river is flown, which causes Surabaya to develop naturally at the northern axis following with the flow of Kali Mas river, causing in a population density higher than the eastern and western regions. The government's strategy in managing the city, implemented the renewal urban program in which is the city center development on east and west. Surabaya as the Indamardi Gaspar areas that covering Industry, Trade, Maritime, Garrison and Tourism, caused the immigrants from different social backgrounds are coming to the city as the urbanist. They enter and live the city corner occupy, including the coastal region by the immigrants who work as fishermen. One of them is the study area of Bulak district on east Surabaya, where the residential conditions have minimal infrastructure in there.

The existence of coastal areas in part of city which has a tourism value, so that it is good when the potential occupancy fishing conditions are still likely to be reorganized in order to increase the quality environment further. Thus the positive aspect for the city and welfare of fishermen improvement can be achieved. The existence of fishermen occupancy on east coast of Kecamatan Bulak Surabaya, inhabited by immigrants who have a livelihood as traditional fishermen. The residential of fishermen were developed on coast along to connect the east coast of Surabaya occupy continued. The immigrant come from the northern coast of Java, who work as fishermen (such as Tuban, Lasem, Rembang, Pasuruan, Probolinggo, Situbondo, Madura and the other area).

The conditions were utilized by the urbanists as a fishing village settlements initially in form of the natural coastal plains and disorganized. The situation of fishermen inhabited is more dense, remains unplanned and irregular develop and dirty impression. The lower classes considered that any vacant land is common property because it was considered that no man's land and anyone can use them according to the needs of individuals and groups both (Poerwanto, 1997). In process of living which at first prospective users can establish in there that is suitable used as a habitable place, established subsequent roughing building as a residence. In course of time, became a fishing village that is solid but the environment condition was not livable. The adaptation act by humans are in order to survive that place is, where the lower classes in process much easier adjustment because this group who have a compact habit and simple character and will try to accept whatever is obtained. The behavior and culture of low-income people who were taken from origin areas before staying in there that impact on the residential containers on the beach location. Where the residential atmosphere is crowded as in the village or commune still coloring the region. "The behavior and culture of the lower classes cannot be deprived of its cultural roots" (Silas, 1990). That is the welfare of fishermen who seem seedy and irregular residence is an application of grassroots activities. 


\section{THEORY / RESEARCH METHODS}

The technical methods of collecting datas in the preparation this study, using "descriptive, qualitative, explorative". The government regulations are used as a lattice arrangement research to adjust the fishing area to develop the city direction that has been planned by the local government. Techniques and modes of collecting data in organizing the study, consist of :

1. Technical Survey :

Interviews technique to the occupants of fishing village have conducted by preparing materials appropriate questions to answer research purposes. The respondents were selected which an old occupant, leaders of fishing organizations who know everything about fishing village from the beginning. They can tell why and how the inhabitants occupy in there. All the proceeds interview rearranged the order, to destination answer include field documentation.

2. Inventory Datas to Research Support :

The datas are intended, including primary datas (the obtained datas of source field and visual study object), and secondary datas (the obtained literature datas related with the study).

Field of data observation in study area, consist of :

1. Physical Data information: Covering a wide range of inputs relating to the physical condition of the study object (such as natural conditions, environmental infrastructure, public facilities, residential conditions of the citizens, ownership status of occupancy, landscape).

2. Economic Data Information: Covering the economic potential of population (such as : skills, business opportunities, ability of fishermen economic level, daily work of citizens, future prospects, residents' needs).

3. Social and Culture Data Information: Covering the habits population related to the behavior and culture of fishing communities with regard to the existence of environment (such as : citizens socialization, kinship and similarity of local origin, citizens relationships beliefs, environment preservation). Knowing the particular norms that exist in fishermen lives, which can encourage the positive and negative on group.

The stage of analyzing by utilizing the variety literature of field data, that obtained of study observation, and support all data.The next step is done by grouping all of the datas according types in order to facilitate through discussion. Step of data analysis in study area, consist of :

1. Physical development analysis, aims : Seeing the potential and limitations datas that exist in field, to measure the extent which to the region can be corrected order. Planning some interrelation strategies, so that the objectives can be achieved without potensial environment damaging and can be maintained.

2. Socio-cultural and economic residents analysis, aims : Avoids the negative impact due to the area development. Formulate of the development policy community. 
Looking for the cooperation form between "the public-private-government" that all parties benefits involved.

\section{RESULTS AND DISCUSSION}

The environment adaptation was done by humans, that will be territories created to show the identity and ownership. The next stage is going to create a strong emotional bond between people (as users) and occupancy (as a place for living). Attachment between humans in a place grew when they live and moving in environment. The bonding occurs naturally, which will strengthen the relationship that involves the emotion, cognition and behavior. Based on the existing conditions, can be explained that "the place attachment is a bond of cognitive, emotional and behavior between the humans and environment inhabited" (Altman \&Chemers, 1984). "While the association with a shelter place, describing the human attachment and occupancy that is the climax of an activities series to inhabit" (Draft Vision, 2013).

The location of study area is located on the east coast of Surabaya there in Kedung Cowek village of Bulak district precisely. There are many groups of fishermen housing arrangements with physical condition did not fulfill as a viable and healthy occupancy. This assessment is based on lack facilities and infrastructure environment, where the location seemed crowded and dirty. The fishermen who inhabit in this region came from the various areas in central Java and east Java. Based on their same background of low-income, then they are very easy to blend in a group of fishermen citizens. The togetherness took place when the fishermen looking for to catch the sea products, that their solution in family problems and economic hardship.

The fishermen sail at $3.00 \mathrm{am}$ in the morning, and returned to the beach at $13.00 \mathrm{pm}$ in the afternoon, but they are caught only small commodities obtained. The commodities are accordance the season, sometimes is small fish (whitefish, red snapper, mackerel, squid), shellfish, and marine animals (sea cucumber, eggplant). The fishermen's wife searches for mussels at the beach assisted in the evening usually. All fishes will be cleaned up by the teenage children, and then marketed in their own dwelling or brought to the market there are around the area of study. They will be brought to the Sentra Bulak center if the sea products are good condition and to be processed into smoked fish and fried food that served with attractive packaging. The Bulak center become for destination domestic tourist that will buy souvenirs of Surabaya, through can see views of the sea there are being addressed and organized by the local government. The fishermen occupancy there are to be reorganized viewing with consideration of roads locations, so that the fishermen residential complex can be exit directly. "The proximity of housing to the workplace for lower classes are very important which for the achievement of saving cost to the work site and that are easy to do any time" (Turner and Fichter, 1971). The existence of fishing village adjacent to the beach location where the road to these places filled with the public transportation that is affordable for citizens utilized. They need the government counseling continuity with simple material of 
building technology, so that the fishing communities were able to improve and develop the residential building independently. The opportunities for new funds with low interest can get (as the economic democracy), it is required to residents improve the occupancy, equipment, and small business. Implementation of coaching fishing communities, involving the three joints economic democracy, that including 'the government-private sector-community'. The coast region is an integral part of fishermen residential which overall is a tourism asset that has economic value for the local government.

Therefore, need to be taken to ensure the integrity and sustainability in region, as well as the nature environment is fulfilled. "Thus the alignment can take place in a dynamic and sustainable development" (Silas, 1993). The flowchart of research can be seen in Figure 1.

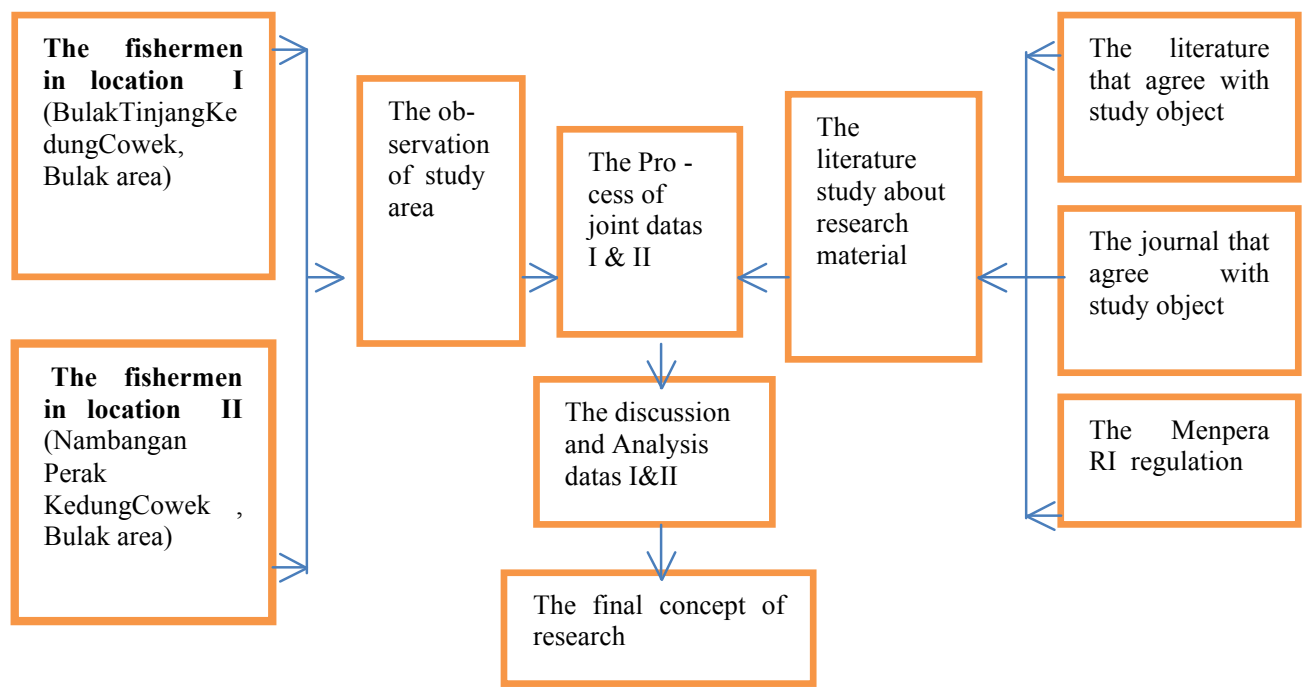

Figure 1. The flowchart of research

According to regulation of The Ministry Housing of Indonesia Republic (2011), that the fishing area instructions in general development, consist of:

1. Housing of fishing areas, herein to the fisher residential area after referred that is dedicated to supporting the activities of maritime affairs and fisheries.

2. Infrastructure of fishing area is urgent physical completeness which allows to work and develop activities related to the maritime affairs and fisheries (such as: the boat docks, etc).

3. Fishing area means the supporting facility that works for maintenance and development the economic, social and cultural life and fishing livelihood (such as: the manufacture nets, etc).

4. Primary infrastructure network is the network of major fishing areas that can connect between the housing unit and other areas, to general infrastructure of road interest. 
The study area, only a portion of the basic needs as required regulations, including occupancy less worth. There are mooring boats that only made of iron stakes plugged in coast and wrapped around rope, a tie boat without a dock, and boats repair by themselves on the beach independently. The fishermen can purchase all of their needs on the Local Credit Unions in Bulak Tinjang Kedung Cowek district and repair all of theirs in shelter residents.

\section{Demographic Observations}

The fishing communities with different regions outside Surabaya have enough compactness level, where the mutual support of each other among all the needs. Each family has many children (up three persons amount), with minimal economic level, low education, so that there are difficult to grow. This condition is likely caused by lack of family planning counseling until them to marry at young age.

\section{Economic Observation}

The fishing communities have limited equipment, that resulting harvesting of fish in less revenue, there are depending the ocean season in each year. The fishermen work in January, February, March, April, September, October, November and December only, while May, June, July and August was minimal turnover caused strong breeze in the sea. The fishermen were obtained through a side funds setting for lean times, until all the needs can be still enough. The fisherman's wife and her children, help to obtain additional funds. They were seeking shellfish at low tide with surfboard and also selling daily necessities such as soap, wash soap, toothpaste, snacks in shelters. The condition of drying fish's place can be seen in Figure 2.

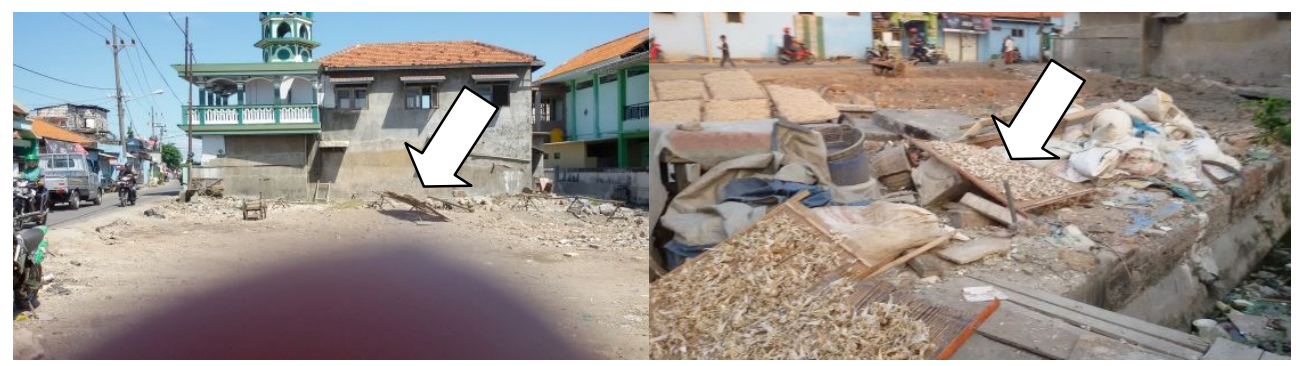

Figure 2. The bad condition of drying fish on open space environment in study area

\section{Social and Culture Conditions}

The characteristics of rural life in fishing communities are coloring the activities of citizens. There are such as friendly, mutual cooperation as togetherness spirit without clear objectives. The positive of social and cultural of fishermen character in terms, they help to each other in various activities with specific needs fulfilled and improved the residential and equipment with togetherness spirit. The familiarity in there is caused the formation of grouping occupancy (such as still brothers in same 
place). The condition have a positive impact (such as sociable in group) and also negative impact (their environment becomes crowded). The situation of coomunities residents can be seen in Figure 3.

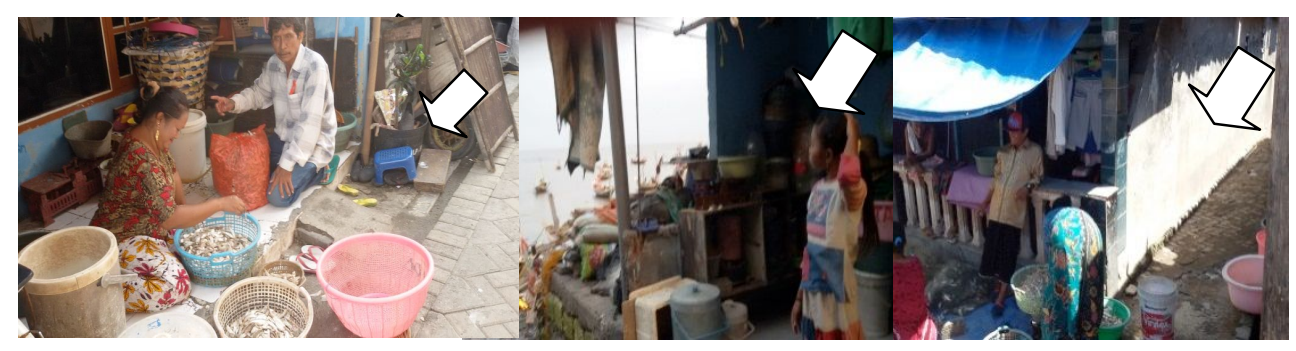

Figure 3. The situation of fishing communities residents in study location

\section{Environmental Conditions}

The bad condition is caused by several factors : (a) Socio-cultural of rural character that corporated of each other and become clustered; (b) Minimal education, makes minimal knowledge of health importance; (c) Each family has many children (more than 3 children) with narrow and more crowded residences; (d) Less economic conditions where the residences cannot be repaired and not well maintained. These datas are used to set the decisions policy, as follows:

1. Environmental improvement targets could be implemented.

2. Find out the economic community improvement, by taking cooperation advantage of "Local government-Private-Public" sectors that must be worked.

3. Avoiding the negative impact on fishing residential due the area was developed.

4. Harnessing the potential area was developed according to master plan city.

5. Achievement associated location with the development of commodity have made.

Base on the strategic development policies that are relevant with residential of fishermen in east coast of Surabaya, as follows:

1. Repairing the settlements of fishermen in coastal areas through the infrastructure facilities that are connected to the potential existing in city.

2. Procurement the settlements with a priority for low-income communities located incoastal areas.

3. Housing development that integrated with the inter-related sectors.

4. Conservation of natural resources for the fisherman generation income.

5. Structuring strategy in fishing area adapted with local government program.

The residential housing sector policies, which can be used to arrange the study of fishing area, as follow:

1. Development of residential and settlements area should be implemented with sectoral approach integrated. The role of local government as an impetus for areas development and provide assistance for less regions. 
2. Development aimed to improve the economic people and expand the employment through of small industries.

3. Housing development program can be geared the economic problem of lowincome communities.

4. Reference of residential housing standard must be used with construction of lowincome housing there are livable.

5. Residential construction would be based on the development concept of community-based as a consumer.

6. Development approach through the area that ready to build and can be integrated with the city.

7. Development strategy should be supported the spatial patterns of low income.

8. Financing of housing construction settlement through the cooperative fund "the state-private-enterprises" joint.

9. Development housing and residential in a particular area will be implemented through large-scale region which is ready to build (such as Kasiba).

10.Increasing community participation through are coaching and counseling (such as environment preservation, family planning, simple technology, etc).

11.Development housing, by increasing the role of regional autonomy preferably.

12. Natural resource management needs through the counseling and services information to be improved (such as : information of water management, fish preservation correctly, etc).

The development of study area cannot be separated from the existing system in the master plan of Surabaya 2007, which developed in the industry, trading, maritime, garrison and tourism fields. To achieve this goal was spreading many centers into the new development, according to hierarchy that integrated the city planning program. The land use policy was related the areas of fisherman community that include all facilities need. The fishermen bend urban renewal area (2013) mentioned the ten strategy of rejuvenating retreat for fishing villages, consist of :

1. Creation of 21 st century jobs.

2. Timely provision of infrastructure.

3. A place that is easy to get around.

4. A vibrant, mix of uses and activities.

5. Distinctive and diverse neighbourhoods.

6. A great place for families.

7. A high quality built environment.

8. Smart environmental solutions.

9. Environmental constraints addressed.

10.Strong partnerships and effective governance.

The tenth strategies above are expected to be developed in the fishermen settlements, which should be tailored to the characteristics of physical and non physical environment. The revitalization of settlement must be taken into the concept of "New Urbanism", which is to improve the city by using the principles of traditional neighborhood. For example, the ease of walking to reach the facility 
without being crossed by heavy vehicle traffic, mix-used in a zone area that is easily and accessible by foot only.

The new urbanism concept is supported by the principles of "smart growth", which can be used to arrange the study of fishing area, consist of :

1. Mixed land uses.

2. Compact building design.

3. A range of housing opportonities and choices.

4. Walkable neighbourhoods.

5. Distinctive, attractive communities with a strong sense of place.

6. Preservations of open spaces, farmland, beauty natural, and environmental.

7. Development directed toward existing communities.

8. A variety of transportation choices.

9. Predictable, fair, and cost effective development.

10. Community and stakeholder collaborations in development decisions.

The ten principles of "smart growth" can be used as a reference for the settlements rejuvenation in the fishing village in Bulak district. The most important of these are the rejuvenation concept how the physical conditions of settlement noticed that include the condition of buildings, infrastructure and all facilities. Nonphysical that more importantly such as the social, economic and cultural community. The participation of community is very important in renewal program implementation. The revitalization of settlement are related to the improvement of neighborhoods quality, where can be seen in physical settlement residence. According with Silas statement (1993), that describes "the house conception of, in its that realization requires unity, wholeness and balance between 'men-houseenvironment', so that the relationship can takes place in a dynamic, sustainable and beneficial mutually". The existence of residents will be sustained when all of the needs can be used the occupants to guarantee their physical development process with the economic household. The Turner statement (1972), said that "the inhabitants are in a position to determine the development housing, which in line with the economic level of the occupant".

The main concept of fishing environment planning of Budihardjo (2005), consist of : "(1) Quantity and quality of sustainable water well maintained, (2) Drainage system is well planned, (3) Management system of the garbage and waste are well planned, (4) Available accessibility on road network and pedestrian, (6) Improvement of physical, and (7) To avoid the danger of abrasion with the embankment applying, and vegetation planting". To improve the fishing settlement quality with vegetation planting in accordance with the characteristics of the land, shelter, and ecological function.

According with Budihardjo (2005) mentions, that "the presence of vegetation, serves as a counterweight to built environment, to aesthetic function addition, shade, as well as air pollution". The presence of open spaces in fishing area (such as specific vegetation area) and existence of water catchment in there are very important, because it serves built environment balancing. The quality of fishing settlement as potential addition also need to be developed and well planned. 
According with Paputungan (2014) stated that, "the development of the fishing settlement could be based on ecotourism. There are three aspects concept of ecotourism, consist of "the quality of the environment, local culture and economy of the community". Theme of tourism development that is characteristic of east zone nautical tourism, there is a vehicle for Surabaya. The main strength should be developed, there are the city park and power image as a maritime city that making coastal tourism where the fishing shelter needs to be organized. The study area is much improved, both in terms of physical residents, environment and infrastructure facilities by the local government that implemented in 2014. The limited funds of local government that caused the new improvements were touched some fishermen settlement area in Bulak Tinjang Kedung Cowek district. The Nambangan Perak Kedung Cowek Bulak district there was minimal improvement.

"The quality of housing environment can be assessed in terms of physical and non physical. A settlement has good criterion, when the physical and nonphysical aspects are fulfilled" (Sumartinah, 2000). The physical aspect can be reviewed on the geographical location, that the environment and infrastructure have built. While non physical aspects must be regards to the social, economic and cultural occupants. According to the Agenda 21 also emphasized that the expansion of settlements, which can improve the quality of life of its inhabitants. There are the concept of integration between social, functional and ecological. Characteristic of fishing village settlements in Kedung Cowek Bulak district, based on of physical and non-physical aspect, which is insaparable in creating housing environment quality. The settlement has been surrounded by social, economic and cultural blend until the settlement becomes functionally and ecologically (Figure 4).

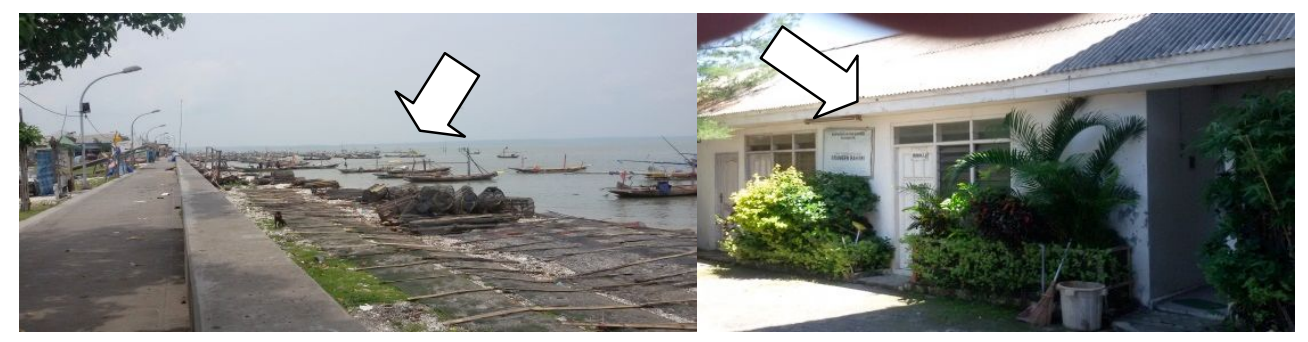

Figure 4. The base boat on shore and the economic enterprise office of Bulak Tinjang

\section{Characteristics of the Informal Settlement in Fishing Village : Condition of Basic Physical Environment}

The fishing village in Bulak Tinjang and Nambangan Perak are located on east coast Surabaya. The Bulak Tinjang fishing settlement existence, reached from two direction ways there are limiting in shore (Kaji Ulum street), and the new way that widened by displacing slums along the road in there (Cumpat street). The settlements of Nambangan Perak Kedung Cowek Bulak district toward in south and west aim, there are at long beach and sea placed. The Nambangan Perak has not been touched by the local government in physical occupancy. While the region of 
Bulak Tinjang was started first in physical occupancy such as facilities and infrastructure. Both of the locations condition that are somewhat different.

The mooring dock in Bulak Tinjang and Nambangan Perak, where the boat is not available in fishing area, all of them were parked on the shore with a harness strap tied with iron planted on beach. Sometimes when a big wave was come, then the boats washed away to the sea. This condition is extremely detrimental for the fishermen, because they should have boats through the cooperation enterprise in Bulak Tinjang. The base boat on site can be seen in Figure 5.

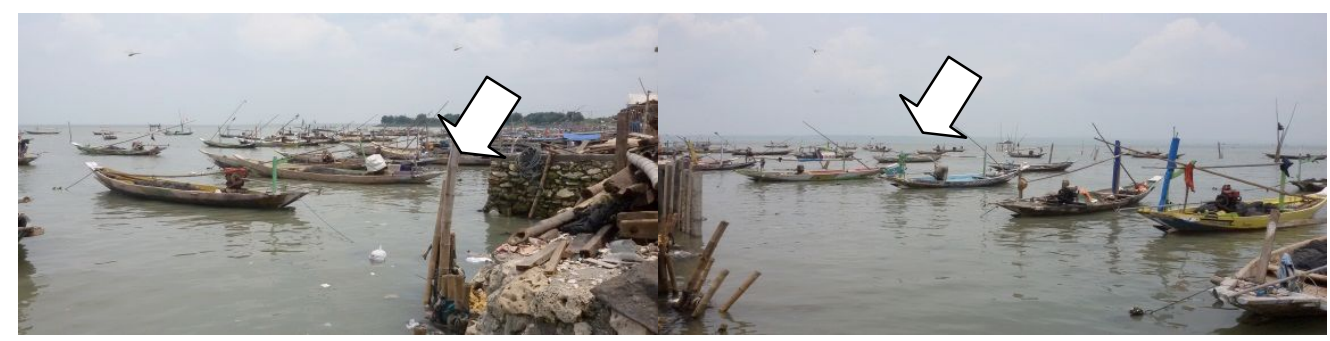

Figure 5. The base boat on site of Nambangan Perak and Bulak Tinjang fishing area

\section{Land Use of Fishermen Area}

The land use of Bulak Tinjang and Nambangan Perak in Bulak fishing village, still dominated for residential areas. The commercial areas in form of shops and stalls are located on highway that on Cumpat and Nambangan street. All of the fishermen have not independent stores in the area, then they also collected the variant of fishes in Fish Center of Bulak on Kejawen Lor Surabaya. The Fish Center of Bulak and the base boat in Bulak Tinjang can be seen in Figure 6.

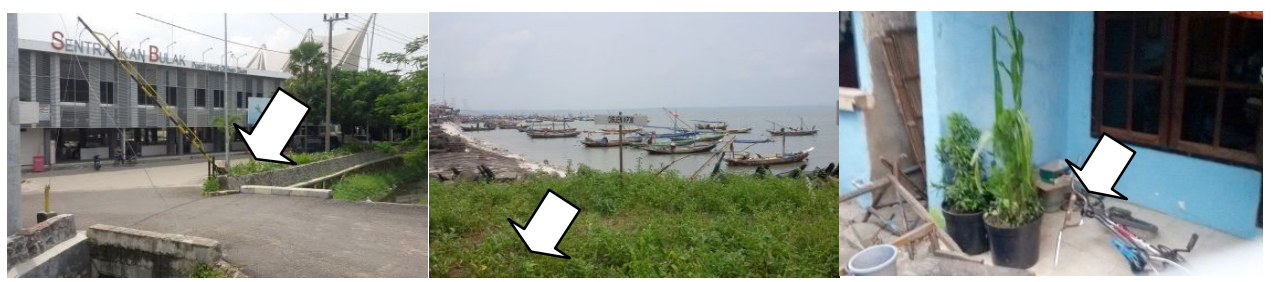

Figure 6. The Sentra Ikan Bulak, the base boat on BulakTinjang fishing, and the resident

The characteristics of two environment (in BulakTinjang and Nambangan Perak) there had dry and flat land which a residential community functioned.

The open spaces for greenery, so that not barren appeard. The trees can grow on the shore, such as mangroves, cherries developed in both locations, because the land has a high salt content. Some residents grow the plants in many pots on a narrow alley. 


\section{CONCLUSIONS}

The condition of fishing settlement still dirty and crowded. They are still needed bathroom and household sewerage in their residents. Apart of them still use traditional habit of harnessing rivers and neglect in hygiene and environmental health. The fishing settlement of Cumpat area, in partial occupancy had begun and equipped with the personal lavatory and physical improvement (from the bamboo plait replaced to brick wall), with funding from the local government. While the fishermen village of Nambangan area still not getting touches because the limited funds conditions, so that the fishing village was minimal improvement and not livable. The fishermen need occupancy for their life.

The relationships of fishermen's life with natural environment can create by themselves on their existing areas dependency. Such as the biological resources that are owned by surrounding the nature especially on the beach that can provide for the livelihood income. The relationship in there must be recognized and to be maintained.

The analysis of study areas has been carried out to establish the concept of settlements in Bulak district, consist of :

1. The utilization of land use should be divided into several zones on settlements. There are some open spaces for placement of residents and shared spaces community. The communal activities such as managing fishing capture with togetherness and changing raw materials into finished things. On Bulak Tinjang location, still allows the process in their open spaces along the driveway bordering sea barrier. While on Nambangan Perak, that the open spaces are spaceless, they do in the Mosque yard and the Kedung Cowek Bulak office area. There are needed supervision integrate at site continuity.

2. The management of financing for the occupants of Bulak Tinjang and Nambangan Perak settlements, should be established cooperation between the fishing communities and local government. The relationship makes it easy for low income level to obtain loans from financial institutions. The activities of participant consist of practitioners and users of development outcomes. The role of local government is needed in coaching and guiding the users with the development programs (such as business development).

3. The implementing housing finance counseling by the government, about some programs such as low interest rate loan with different purposes (eg. Facilities of housing repairs and improvement, environment development, etc).

4. The establishing partnerships with the private sector, such as cross-subsidized within the people. The distribute tax payments obligation from the upper class who can afforded and to be given to the lower class occupants. Government as the driving force and facility providers should be distributed in lending procurement and housing improvement, which is in rural areas. The outreach activities of funds is not known for the community wider, until they cannot get to use the program. The public participation also need to be improved especially in financial, so that the program can be running well.

5. There are some simulation process in sustainable neighbourhoods. They also can renew the contract to create new condition by themselves. 
6. Sustainability issues have been reflected in promoting urban settlement, that emphasizes on sensible exploitation of natural resources. It is a manner to allows the future generations repeating all process.

7. Revitalizing action of failing urban area to restore economic vitality and improve safety area through the development or redevelopment either. Redeveloping an urban area is harder and costly than if building a new development location.

8. Such of developed fishing area is also beneficial to fulfill community needs concerning on economic potential.

\section{RECOMMENDATIONS}

The result observation on Bulak Tinjang location show that the condition was not complete and perfect repair. While on Nambangan Perak location show that the condition is untouchable in physical and environmental improvements. The local government must be done the steps as follows :

1. The fishermen must be given counseling immediately in obtaining soft loans, so that they could have private houses in installments of Bank's authority or Economic Enterprise. The community participation with government is needed for renewal settlement in the fishing village. Without their involvement the renewal strategy could not be run well.

2. The guidance of local government was needed on various small business opportunities, which the process is not complicated and profitable for the low income people.

3. The condition of facilities and infrastructure in fishing area are not rectified by affected giving immediately, including if the fishermen in carrying out their repairs. They have to demonstrate between 'man-houses-environment' balance, so that the relation between theirs can be dynamic and sustainable.

4. The existence of houses in fishing area needed a private bathroom with good sanitation and septic tanks. The environment can be preserved from the water and waste pollution, so that the area is livable and healthy.

5. The environment conditions in fishing area cannot be developed, if the fishermen community have minimal economic standard. They need to obtain the economic opportunities are promising for low-income level.

6. The environment in coastal area has needed for electricity services evenly in the study area (location in Bulak Tinjang and Nambangan Perak), that fulfilled with settlement. If the environment lighting and safety area can be realized, so that Surabaya as maritime city can be succeeded. 


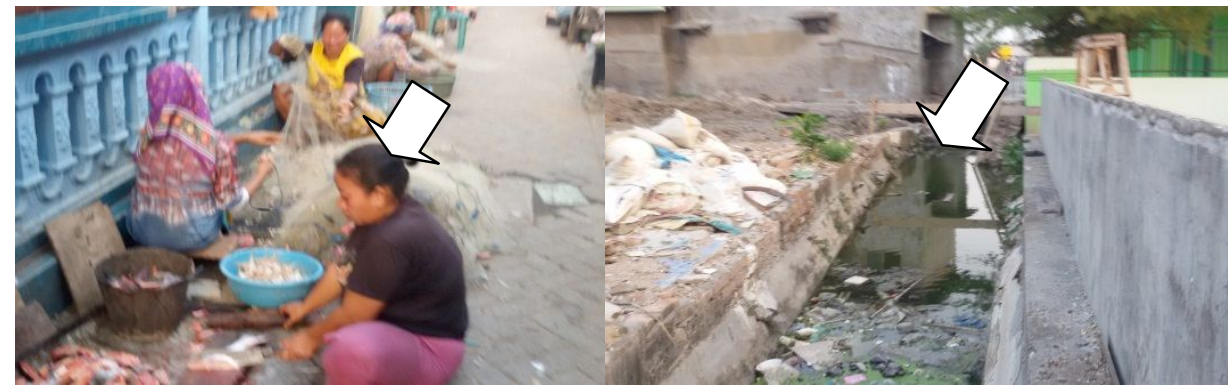

Figure 7. The bad condition in study areas location (Bulak district area)

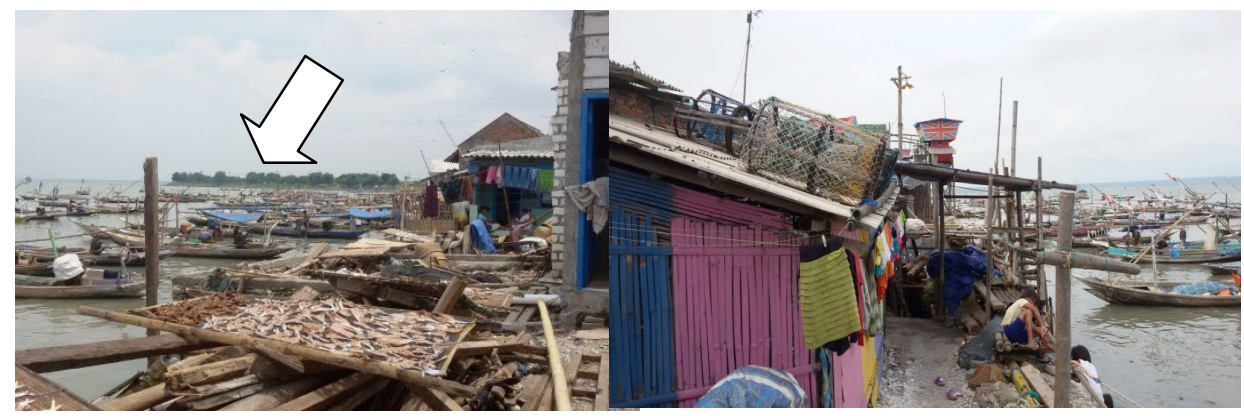

Figure 8. The fishermen environment in Bulak coastal areas have needed electricity services that must be improved by the "Local Government-Private-Public"

\section{REFERENCES :}

Altman; Chemers (1984), Culture and Environment, A Division of Wadsworth, The University of Utah Books Cole Publishing Company California.

Budiharjo (2005), Kota Berwawasan Lingkungan, PT Alumni Bandung, Bandung.

Draft Vision (2013), Fisherman Bend Urban Renewal Area, Places Victoria, Melbourne.

Darmiwati, R. (2001), Perencanaan PermukimanNelayan di Pantai Timur Surabaya, Journal Dimensi Teknik Arsitektur, Vol. 29 No. 2.

Dahliani; Susy, B.,A.; Darmiwati, R.; Sumartinah, H., R.; Silas,J. (2015), Settlement Renewal Strategies Based on Physical and Non-Physical Characteristics in Kalisari Fishermen Settlement, Surabaya-Indonesia, Humanities and Social Sciences, Science Publishing Group.

Ernawi, I.,S. (2012), Mengintegrasikan Smart Growth ke dalam Sisitem Penataan Ruang Indonesia, Berita Penataan Ruang, Ditjen Penataan Ruang PU (online, available : http://www.penataan ruang.net/detail_b.asp?id=2015 (March, 30, 2015). 
Paputungan, S., M. (2014), Arahan Pengembangan Permukiman Nelayan Berbasis Ekowisata, Studi kasus : Pesisir Pantai Malalayang, Kelurahan Malalayang I dan Malalayang I Timur, Kecamatan Malalayang, Manado, Journal Sabua, Vol.6 No.3.

Pemerintah RI, Menpera (2011), Undang-Undang No.1 Tentang Perumahandan Permukiman.

Poerwanto, H. (1997), Manusia, Kebudayaan Dan Lingkungan, Direktorat Jenderal Dikti Depdikbud RI dan Pusat Penelitian Lingkungan Hidup, Universitas Gajah Mada, Yogyakarta.

Silas, J. (1993), Perumahan Hunian da Fungsi Lebihnya, dari Aspek Sumberdaya dan Eksistensi, Inagural of Profesor of Architecture, FTSP-ITS Surabaya.

Sumartinah, R., H. (2000), Permukiman dan Lingkungan dalam Pengembangan Wilayah, Pidato Pengukuhan Guru BesarArsitektur FTSP-ITS Surabaya.

Turner, J.,F.C.; Robert, F. (1972), Freedom To Build, The Macmillan Company, New York, and Collier Macmillan, Limited, London. 
Darmiwati : THE NEW URBANISM OF FISHERMEN'S VILLAGE IN BULAK SETTLEMENT SURABAYA

This page is intentionally left blank 